\title{
FACTUAL SUPPORT OF THE GUILTY PLEA AND SENTENCE BARGAINING DURING THE CRIMINAL PROCEDURE - THE MACEDONIAN EXPERIENCE
}

\author{
Boban Misoski, PhD, Associate professor \\ University "Ss. Cyril and Methodius", Skopje, \\ Faculty of Law "Iustinianus Primus", Chair of Criminal Procedure Law \\ bul. Goce Delcev No. 9b, Skopje, North Macedonia \\ b.misoski@pf.ukim.edu.mk
}

\begin{abstract}
As part of its EU accession agenda, Republic of North Macedonia has performed series of reforms of its legal system in order to reach EU legal standards. As part of this agenda, improvement of the efficiency of the criminal trials was marked as highly relevant. New Law on Criminal Procedure, consisting many modern adversarial trial instruments, enacted in 2010, supposed to improve the efficiency of the Macedonian criminal trials. However, after a certain period we deem that it is necessary to reevaluate the effects of these reforms and their practical implementation. Hence, the author evaluates the Macedonian court's practice of implementation of the defendant's guilty plea during the main hearing of the criminal procedure together with the reasons for decline in the use of these instruments into the court's practice. The main reasons for such decline of the implementation in practice can be located in several areas. Such areas are improper implementation of the law, legal imperfections together with the length of the criminal trials, lesser sanctioning policy and absence of proper instrument for providing of the expected sentence as an outcome from the bargaining procedure. However, besides these already known weak areas concerning the implementation of these instruments in practice the author has detected an additional problematic area about the factual support of the guilty plea during the main hearing. In addition, the author analyzes the practice of evaluation of additional evidence in case of guilty plea, and the amount and the quality of evidence provided by the prosecutor as support to the defendant's guilty plea. Author concludes that there is a gap between the theoretical definitions of the guilty plea and its practical implementation, and provides practical proposals for improvement of the provisions of the Law on Criminal Procedure. He concludes that these amendments are necessary for proper implementation of the Law and of the protection of the defendant's rights and pertaining the impression of just criminal procedure in cases when defendant pleads guilty.
\end{abstract}

Keywords: sentence bargaining, guilty plea, evidence, factual support 


\section{INTRODUCTION}

As part of its EU accession process, Republic of North Macedonia has undertaken vast reform of the national criminal justice system in the past decade. In this sense, we are counting ten years from the enactment of the new Law on Criminal Procedure (LCP) ${ }^{1}$ as part of the reform process inspired and designed to increase the efficiency and effectiveness of the criminal justice system, together with the need to increase the level of trust and confidence in the system and to improve the defendant's rights. Finally, one of the main goals of this reform was trough the improvement of the fairness of the criminal procedure to advance the legitimacy of the criminal trials, and to accept and implement the EU acquis in the area of criminal justice into the national system.

One of the biggest changes on this path was the enactment of the new Law on Criminal Procedure. This Law on Criminal Procedure was enacted in 2010 and has marked the biggest shift of the concept of the criminal procedure from inquisitorial, or euro-continental criminal procedure, towards more adversarial criminal trial. ${ }^{2}$ However, besides this shift from the legal doctrine, the new LCP has also incorporated the latest trends of the evolution of the protection of the defendant's rights as already sketched in several EU Directives and determined from the ECtHR practice. The most notable novelties of the Macedonian criminal justice system reform, were the introduction of guilty plea and sentence bargaining ${ }^{3}$ as part of this adversarial criminal procedure. Besides the complete restructure of the main hearing, most important contextual changes of LCP are the passivation of the judge during the investigative phase and main hearing, together with the im-

Official Gazette of the Republic of Macedonia, no 150/2010

2 See: Matovski, N.; Kalajdziev, G., 'Efficiency of Prosecutorial Investigation in Contrast to Efficiency of the Defense in Reformed Criminal Procedure (with a particular view of the new Macedonian CPC)', in: Jovanović, I.; Petrović-Jovanović, A., (eds.), Prosecutorial investigation regional criminal procedure legislation and experiences in application, OSCE Mission to Serbia, 2014; Buzarovska, G.; Kalajdziev, G., 'Reform of the Criminal Procedure in the Republic of Macedonia', Iustinianus Primus Law Review, vol. 1 , no. 1,2010

3 These two aspects or instruments of the criminal procedure, also recognized by the CoE's Recommendation No. (87) 18, of the Committee of Ministers to Member States Concerning the Simplification of the Criminal Justice, were envisioned as one of the so-called "holy grail" instruments, which would increase the effectiveness and efficiency of the criminal trials in Republic of North Macedonia, while at the same time with equal success would protect defendants' rights to fair trial. Also see: Buzarovska, G.; Misoski, B., 'Plea Bargaining under the CPC of the Republic of Macedonia', in: Jovanovic, I.; Stanisavljevic, M. (eds.), Simplified Forms of Procedures in Criminal Matters - Regional Criminal Procedure Legislation and Experiences in Application, OSCE Mission to Serbia, 2013 
provement of the position of the prosecutor during the investigative phase as sole and most important figure for gathering and investigating evidence. ${ }^{4}$

Since 10 years have elapsed from the enactment of this completely new in concept LCP, and more than 7 of its practical implementation, we deem that we have appropriate time distance for evaluation of the effects of these newly introduced legal transplants into our modernized criminal procedure doctrine and courts' practice.

Considering the implementation of the sentence bargaining and guilty plea, it is fair to mention that immediately after the enactment of the new LCP in 2010 the criminal justice professionals were divided regarding the dilemma whether sentence bargaining and guilty plea is the real answer to clean-up the court dockets and speeding up the criminal trials. Hence, there were doubts in these institutes whether they offer fair and just model that can generate just judgments having into consideration Macedonian legal mentality.

The dilemmas regarding the introduction of these instruments were present since they are controversial even in their founding legal systems, such as US legal system and the UK legal system. ${ }^{6}$ Furthermore, from comparative perspective, there are many ongoing discussions and debates concerning its fairness and open questions remain regarding its proper implementation. ${ }^{7}$ Since from the enactment of the sentence bargaining and guilty plea several problematic areas are present, we think that it is appropriate to reevaluate their practical and proper implementation in the Macedonian criminal justice system. Main issues that have risen from its implementation, so far, are issues based upon legal imperfections together with the length of the criminal trials, lesser sanctioning policy and absence of proper instrument for providing of the expected sentence as an outcome from the bar-

4 Калајџиев, Г., 'Замки и заблуди на реформата на истрагата' іп Зборник на трудови на Правните факултети во Скопје и Загреб, ПФ Скопје/PF Zagreb 2009; Kalajdziev, G. et al.,'Rearrangement of the Main Hearing in Republic of Macedonia', МРКПК, 6р. 2-3, 2008, pp. 213-234

5 Although, more structured dialogues were more frequent in our surroundings states than in North Macedonia, since, somehow this trend of modernizing the criminal procedure was simultaneous in the area of Western Balkan states. See: Jovanovic, I.; Stanisavljevic, M. (eds.), 'Simplified Forms of Procedures in Criminal Matters - Regional Criminal Procedure Legislation and Experiences in Application', OSCE Mission to Serbia, 2013

6 See: Fisher, G., 'Plea bargaining's triumph: a history of plea bargaining in America', Stanford University Press, 2003; McConville, M., 'Plea Bargaining: Ethics and Politics', Journal of Law and Society, vol. 25, no. 4, 1998, pp. 562-587

7 See: Herzog, S., 'Public support for Plea Bargaining Practices', Crime and Delinquency, vol. 50, no 4, 2004; Boari, N.; Fiorentini, G., 'An Economic Analysis of Plea Bargaining: the Incentives of the Parties in the Mixed Penal System', International Review of Law and Economics, vol. 21, no. 2, June, 2001, pp. 213-231; Yue, M., 'Prosecutorial Discretion and Plea Bargaining in the USA, Germany, France and Italy: A Comparative Perspective', International Criminal Justice Review, vol. 12, 2001, pp. 22-48 
gaining procedure. Finally, the level of persuasion of the court while accepting the guilty plea or draft-settlement as result of the sentence bargaining has risen as one of the main obstacles that diminish the public trust into the fairness of these instruments in Republic of North Macedonia. In order to have proper evaluation of these dilemmas, we think that initially it is necessary to make a brief legal explanation of the concept of the LCP's provisions that regulates these two legal transplants.

\section{GUILTY PLEA AND SENTENCE BARGAINING IN LCP OF THE REPUBLIC OF NORTH MACEDONIA}

The LCP regulates sentence bargaining and guilty plea with several articles. More specific, the sentence bargaining is regulated within the provisions of the Chapter 29 of the LCP, which statutes the implementation of this institute during the early stages of the criminal procedure. ${ }^{8}$

2.1. This means that, in essence, sentence bargaining is generally defined as an instrument for early resolution of the criminal case during the investigative phase, while guilty plea is reserved for the later stages of the criminal procedure. Hence, further specific of Macedonian sentence bargaining procedure is the absence of the explicit guilty plea for introduction of this instrument during the pretrial procedure. The theory behind this legislative decision rests upon two facts. The first one is that at this stage it is too early to discuss the formal guilty plea, since in this phase there is no formal indictment submitted to the court. In addition, during this phase the court is still not involved regarding the factual determination of the guilt, since, as regulated in the LCP, only the court determines the guilt of the defendant in a criminal case. Due to this, at this stage the court serves only as a guarantee for the legality of the undertaken legal actions of the prosecutor and protector of suspect's rights. Additionally in some cases, it might be possible that the whole evidence is not discovered or known to the prosecution, and due to this the prosecution might not expect that suspect will plead guilty.

As regulated within the Macedonian LCP, implementation of the sentence bargaining procedure during the investigative phase of the criminal trial rests solely upon the wish of the suspect. Hence, the suspect, together with his attorney, can enter into sentence bargaining procedure, where they can bargaining only over the

See: Buzarovska, G.; Misoski, B., 'Plea Bargaining in the New Law on Criminal Procedure in Republic of Macedonia', Iustinianus Primus Law Review, vol. 1, no. 2 2010; Misoski, B., "Delayed Justice-Macedonian Experience with Guilty Plea and Sentence Bargaining", SEEU Review, vol. 11, issue 1. 2016, available online: [https://content.sciendo.com/view/journals/seeur/11/1/article-p99.xml], accessed 20. June 2020 
type and severity of the criminal sanction, while it is not allowed bargaining over the composition of the charges due to the strict principle of legality of charging. The consequences of these provisions is that the prosecutor is obliged to prosecute or indict for every crime that the suspect has committed, and at this stage the decision to step into early and speedy resolution of the criminal case rests solely upon the decision of the suspects.

In cases when a suspect decides to enter into bargaining with the prosecution, during the bargaining process over the types and severity of the criminal sanctions, the prosecutor and suspect together with defense attorney ${ }^{9}$ should reach mutual acceptable solution transformed into a draft-settlement that must be verified by the court. ${ }^{10}$ The suspect is entitled to express his defense freely and he/she cannot be forced to accept the settlement. The suspect does not have any obligation to provide facts that will harm him/her or his/hers close relatives and has a privilege of non-self-incrimination. Furthermore, he/she has a right to state all the relevant facts that may be of benefit to his/hers position. In virtue of this solution, an addition to the draft - settlement could only be the request for reparation of the damages submitted by the victim of the crime. ${ }^{11}$ However, the indemnification request cannot be something upon which the suspect and the prosecutor can bargain over. This means that within the draft-settlement the request for indemnification by the damaged person can be only accepted in full as it was requested earlier or it would not be part of the draft-settlement. In later case the damaged person will be informed to exercise his/hers right to indemnification in civil procedure. Hence, by virtue of his authority, the Public prosecutor protects the rights of the damaged person, but the damaged person is not an active participant of the sentence bargaining process. Finally, constituent part of the draft - settlement is the proposed sanction of a certain type and severity, which can be mitigated to the legal minimum for the particular criminal act determined in the Criminal Code. ${ }^{12}$

During the phase of sentence bargaining, the pretrial phase judge in charge of evaluating the legality and willingness of the parties to submit the draft-settlement is not involved in the process of bargaining between the parties. ${ }^{13}$ Through this legal provision, the judge would keep its unbiased position and would not be affected by the statements given by the parties during the sentence bargaining

\footnotetext{
$9 \quad$ See article 74 , LCP

10 See: articles 483 to 490 , LCP

11 See: article 483, LCP

12 See: particularly articles 484 to 487 , LCP

13 See: article 487, LCP, Misoski, B.; Ilikj Dimoski, D., 'Judges' Role in the Evaluation of the Defendant's Plea within the Sentence Bargaining Procedure', Journal of the Faculty of Security, University St. Klement of Ohrid, Bitola, 2016
} 
procedure. This solution is in essence very close to the original model and desired role of the court during the bargaining process. ${ }^{14}$

The pretrial phase judge decides upon the submitted draft-settlement, as noted above. ${ }^{15}$ The pretrial phase judge evaluates the legality of the draft - settlement at a special hearing. At this hearing, pretrial judge particularly examines whether the draft - settlement is voluntarily submitted and whether the defendant is aware of and understands the legal consequences of the court's acceptance of the draft - settlement. Furthermore, the court examines the consequences related to the request of the damaged person for restitution of the damages if it is included in the draft - settlement, together with the court fees. During this phase, the parties can withdraw from the submitted draft-settlement, but if they do not, and if the court accepts it, then the court delivers verdict, which is final, and cannot be objected by the parties with the regular legal remedies. ${ }^{16}$

There are two possibilities for the parties to depart from already submitted draft - settlement. The first possibility for the parties to withdraw from the submitted $\mathrm{draft}$ - settlement is in the phase when the court is examining this draft-settlement where the parties can express its grounds and reasons for non-acceptance. This practically covers the cases when the draft-settlement was not voluntary, if it was exhorted by force by the prosecutor, or if parties have broken their promises given during the bargaining process. Second possibility covers the situation when the court does not accept the submitted draft-settlement due to fact that the proposed sanction does not adequately reflect the conditions and factual basis determined by the submitted evidence enclosed to the draft - settlement. In these both possibilities, the court delivers formal decision for rejection of the draft - settlement.

Providing the opportunity to the pretrial phase judge to evaluate the enclosed list of evidence in support to the submitted draft-settlement, basically, means that the Macedonian legislator has accepted the solution where the draft - settlement must be grounded with sufficient evidence in order for the court to accept it. Henceforward, in essence the court, besides evaluating the legality and voluntary nature of the settlement, must examine whether there is enough evidence in support of the court's verdict. ${ }^{17}$

\footnotetext{
14 See: Alschuler, A. W., 'The Trial Judge's Role in Plea Bargaining, Part I', Columbia Law Review, vol. 76, no. 7, 1976, pp. 1059-1154

15 See: article 485, LCP

16 See: article 488, LCP

17 See: article 489, LCP
} 
2.2. On the other hand, guilty plea under the Macedonian LCP can be submitted to the court on three occasions. In any of these cases, prior to the guilty plea given by the defendant, there must be formal indictment submitted by the public prosecutor to the court. First possibility for the defendant to plead guilty is upon receiving the indictment. ${ }^{18}$ Second possibility for the defendant to plead guilty is during the phase of examination of the legality of the submitted indictment, ${ }^{19}$ while the third possibility is during defendant's first hearing of the trial. ${ }^{20}$

In any of these cases the defendant can plead guilty for one, several or every account of the indictment. In such case, the judge or the judicial council, depending on the severity of the crime, must schedule a hearing to determine whether the defendant's guilty plea is voluntarily and whether the defendant is aware of the legal consequences of the guilty plea. The court must also evaluate whether there is enough evidence supporting the defendant's guilty plea.

In order to prevent any misuse of the defendant's guilty plea in further court proceedings, the LCP prohibits the court to use defendant's guilty plea in any subsequent phases of the criminal trial if this guilty plea was rejected by the court. In such cases any records that contain the defendants guilty plea are put aside of the case file and cannot be used in any further court proceedings. ${ }^{21}$

Guilty plea submitted before the main hearing of the criminal trial, serves as a starting point for initiation of the sentence bargaining procedure. ${ }^{22}$ This means that in cases when the indictment is submitted, defendant's guilty plea is a starting point for commencement of the sentence bargaining procedure between the defendant and his/hers defense attorney and the public prosecutor. In such case, the same provisions that are regulating the sentence bargaining procedure during the investigative phase of the criminal procedure are in power for regulating the sentence bargaining procedure during the phase of control of the indictment. ${ }^{23}$ If both parties reach mutual acceptable solution regarding the type and severity of criminal sanction, they submit the draft-settlement to the court. Prior to the evaluation of the submitted draft-settlement, court must determine that the guilty plea was voluntary and intelligent, and after that, court evaluates the submitted

\footnotetext{
18 See: articles 329 and 330, LCP

19 See: articles 333 to 336 , LCP

20 See: articles 380, 381, LCP

21 See: article 335, LCP

22 See: article 334, LCP

23 See: articles 335 and 485, LCP
} 
draft-settlement upon the same grounds as the evaluation of the draft-settlement during the investigative phase. ${ }^{24}$

If the defendant pleads guilty at the first hearing of the main trial, then the procedure is slightly different and the parties will not commence the sentence bargaining procedure. In such cases, the court will only shorten the evidentiary phase of the main hearing and will examine only the evidence that are important for deliberating the type and severity of sanction upon the crimes for which the defendant has pleaded guilty. Guilty plea can be submitted to the court immediately after the opening statements from the parties, and before the procedure for presentation of the evidence of the parties. In such situation, the court is also obliged to evaluate whether the defendant's guilty plea is intelligent and voluntary. ${ }^{25}$

It has to be noted that the court does not allow the parties to bargain over the sentence. It means that in this case, the court may mitigate the sanction upon the defendant's guilty plea, but this is not mandatory, since this guilty plea is considered only as a mean for abbreviation of the evidentiary phase of the main hearing and due to this, the court must provide elaborate explanation for this mitigation within the verdict's rationale. When the evidentiary hearing, as part of the main hearing, is abbreviated due to the defendant's guilty plea, the court will deliberate the verdict taking into consideration the guilty plea together with the presented evidence. Upon the verdict where the court has accepted the defendant's guilty plea, the parties are not allowed to submit legal remedies for undetermined factual state. ${ }^{26}$

In cases when court does not accept the defendant's guilty plea, the main hearing will proceed with regular dynamics.

\section{PRACTICAL PROBLEMS IN THE IMPLEMENTATION OF THE GUILTY PLEA AND SENTENCE BARGAINING}

Considering the fact that legal transplants are, in most cases, adapted to the legal culture and local tradition, it is possible that sometimes even the noblest ideas will lose their edge within the practical implementation. We can state that something similar happened to the Macedonian experience with the sentence bargaining and guilty plea instruments that were initially introduced as a specific tool for improvement of the national legal system.

\footnotetext{
24 See: article 334, LCP

25 See: article 381, LCP

26 See: article 381, LCP
} 
At the beginning, we should state the most obvious fact that these instruments are not used as frequently as the legislator expected, and due to this, in a sense they have failed with their mission to reduce the court dockets and save the scarce court resources.

Statistically, the level of resolved cases using these legal instruments has declined over the years of their implementation. ${ }^{27}$ For example, an $\mathrm{NGO}^{28}$ that monitors court proceedings in Republic of North Macedonia in its Annual reports have noticed that the numbers have dropped from 40 guilty pleas in 2017, over 26 in 2018, to just 7 in 2019. The same situation can be observed from the Annual reports from the courts and Public Prosecution Offices. For example, State Prosecution for Organized Crime and Corruption have concluded 36 draft-settlements in 2014-th, 28 in 2015-th, 19 in 2016-th, 2 in 2017 and 9 in 2019. ${ }^{29}$

Reasons for such decline might be located in several aspects. First aspect is the legal imperfection that has provided several legal lacunas particularly in the interpretation of the idea of these legal provisions. Additional reason for this was the absence of legal documents or commentaries from the higher courts, such as legal opinions or general guidelines for judges that would provide further theoretical and practical support to the practitioners in the implementation of these legal instruments. ${ }^{30}$

27 See the data from the Annual reports of the courts available on: [http://www.sud.mk/wps/ portal/osskopje1/sud/izvestai/svi/!ut/p/z1/hZDBboJAEIafxQNHmTFQWL2tltIqjYmVCnNpgGwXEmDNukj691LrpUmlc5vJ9_2TGSBIgNrsXMnMVKrN6qFPyfuY46M3 W64w2m58hvw1 DqI4fFlHDy4croAXui6yDUbsbbdEHqDP9nOO4RMCjfvvQEBFp7VoDaRGd-IWOeJ8R-Kd4jj49B-yBpK1yn8O5G3uMAmkxafQQtudHsalMcfTwkIL-763pVKyFnahGgv_Ukp1MpD8JuH5 umf8O8cmbqYJTin_cno5mVwA7bpoKQ!!/dz/d5/ L2dBISEvZ0FBIS9nQSEh/?categoryValue=\%2Fpublic_design\%2FIzvestaii\%2FTip_na_izvestaii\%2FGodisen \&yearCat=0\&reportTypeSel=\%2Fpublic_design $\% 2$ FIzvestaii\%2FTip_na_izvestaii\%2FGodisen], accessed 20. June 2020

28 See: Misoski, B.; Avramovski, D.; Petrovska, N., Anlysis of the Data Collected from the Court Proceeding Monitored in 2017', Coalition All for Fair Trials, Skopje, OSCE, 2018; Misoski, B.; Avramovski, D.; Petrovska, N., 'Anlysis of the Data Collected from the Court Proceeding Monitored in 2018', Coalition All for Fair Trials, Skopje, OSCE, 2019; Misoski, B.; Avramovski, D.; Petrovska, N., 'Anlysis of the Data Collected from the Court Proceeding Monitored in 2017', Coalition All for Fair Trials, Skopje, OSCE, 2020

29 See the Annual Reports of the Public prosecution Office in Republic of North Macedonia, available: [http://jorm.gov.mk/category/dokumenti/izvestai/], accessed 20. June 2020

30 In this sense, even the Prosecutors Bylaws that ware enacted by the State Prosecution Office in 2013 in order to improve and unify the prosecutors' practice while implementing sentence bargaining and guilty plea are declared as confidential and are unavailable for further public scrutiny and possible improvement 
Another problem, that supports this reduction of the practical implementation of these instruments, may be based upon the lenient court policy towards the perpetrators of the crimes. The combination of lenient court sanctioning policy and the length of the criminal procedure instigates the perpetrators to lose their incentive for speedy resolution of the criminal trial. ${ }^{31}$ In this sense, we conclude that in cases when the court procedure is lengthy, with no guarantee that the outcome will be final in near future, the defendants might be motivated to play with the length of the criminal procedure rather than its outcome. Furthermore, in such cases defendants may hope that some evidence will not be available to be discovered in front of the court or they can successfully tamper them, or even in some cases they hope that the statutory limitations for criminal prosecution may appear. ${ }^{32}$

In addition to the lenient court's sanctioning policy, another factor is the lack of guidelines for expected criminal sanction. ${ }^{33}$ Henceforward, absence of an instrument for expected sanction delivered as result of guilty plea or participation in the sentence bargaining has great impact towards the decrease of the popularity of these measures. ${ }^{34}$ This results in a situation where the defendants are not aware, or cannot recognize the benefits from their participation within these legal mechanisms for acceleration of the criminal procedure, nor can they feel in their own case that the court acknowledges and adequately accredits their participatory or constructive role during the criminal procedure.

31 Seе: Груевска Дракулевски, А.; Мисоски, Б., 'Компаративна анализа на механизмите на упатства за одмеруваюе казна: Упатството за одмеруваюе казни во САД', МРКПК, год. 21, бp. 1, 2014, available at: [http://maclc.mk/Upload/Documents/06.pdf], accessed 20. June 2020

32 For example, this has happened on one of the cases called 'Traektorija' from Special Prosecution Office in Charge for prosecuting the perpetrators of the crimes appeared or connected with illegally wiretapped communications. See: Petrovska, N.; Amet, S.; Hadzizafirov, Z., 'Efficient Criminal Justice: Analysis of the SPO Cases, FIOOM, 2020, (in Macedonian), available at: [https://all4fairtrials.org.mk/ wp-content/uploads/2020/04/BP-TA2020-FK-MKD.pdf], accessed 20. June 2020

33 Historically, in 2016 a Law on determining of the type and severity of the criminal sanctions was enacted, which is now void, due to its controversial decisions. See more: Каневчев, М., За некои (контроверзни) решенија од Законот за определуване на видот и одмеруване на висината на казната, МРКПК, год. 24, бр. 1, 2017, available at: [http://maclc.mk/Upload/Documents/Metodija\%20Kanevchev\%202.pdf], accessed 20. June 2020; Тупанчески, Н.; Деаноска Трендафилова, А., Една година од примената на Законот за одредуване на видот и одмеруваюе на висината на казната - проблеми и предизвищи, МРКПК, год. 24, бр. 1, 2017, available at: [http://maclc.mk/Upload/Documents/Tupanceski,\%20Deanoska.pdf], accessed 20. June 2020; Лажетиќ Бужаровска, Г., 'Невоедначената казнена политика и нејзиното влијание врз спогодуваюето за кривична санкција според Законот за кривичната постапка', МРКПК, год. 21, бр. 1, 2014, available at: [http://maclc.mk/Upload/Documents/03.pdf], accessed 20. June 2020

34 For example similar to the UK sentence canvasing, see more: Sprack, J., A Practical Approach to Criminal Procedure, Oxford University Press, 10-th Edition 2005, pp 92 
Due to this, guilty plea or sentence bargaining as specific instruments, are until now mostly used only for resolution of the court cases for lesser crimes, for which the sanction is up to 5 years of imprisonment and where the summary criminal procedure is commenced. ${ }^{35}$

Poor practice of implementation of these provisions in action is creating an environment where these instruments might be abused by the courts in specific cases without considering the defendants' rights. This not only decreases the number of such cases, but also diminishes the public trust in the courts. In addition, improper use of these instruments may in fact protect the real perpetrators and use the defendants as scapegoat. Due to this, in some cases the unbiased spectator can easily conclude that the judges may even glorify the suspects' or defendants' guilty plea without taking any consideration regarding the factual support of this plea.

Finally, besides the abovementioned reasons for such declined number of sentence bargaining and guilty plea by the Macedonian courts, another reason may be based upon the controversial nature of these measures. ${ }^{36}$ Due to this, defendants, prosecutors and judges are not always expressively prepared to use these measures without serious doubt into their fairness and justness.

This list of reasons for such poor practical implementation of these instruments is not exhausted, and they raise vast dilemmas and request further analysis in order to provide specific answers for their improvement. Furthermore, we can comment that most of them are similar and exist in other criminal justice systems that have opted to implement guilty plea and plea-bargaining as a tools for improving the courts efficiency.

However, it seems that North Macedonia, rather shy, but obvious casts another specific malpractice of the guilty plea and sentence bargaining. This is primarily based on the level of factual support and requested evidence of the guilty plea. Hence, we have observed the practice ${ }^{37}$ where the judges were reluctant to examine further factual support to the guilty plea and sentence bargaining when these instruments were introduced in front of the courts. In addition, they were more prone to accept these guilty pleas and draft settlements without scrutinizing the factual support behind them.

See, for example, Annual Report of the Data from the court proceedings, Coalition All for Fair Trials of 2017, 2018 and 2019

36 For the discussions, see supra note no. 6

37 See: Annual Report of the Data from the court proceedings, Coalition All for Fair Trials of 2019 


\section{LEVEL OF FACTUAL SUPPORT OF THE GUILTY PLEA AND DRAFT-SETTLEMENT}

The level of factual support of the guilty plea or the burden of persuasion of the court rests upon the prosecutor. This means that the prosecutor must discover sufficient amount of evidence in order to support the court's decision for accepting the sentence bargaining agreement, or to have sufficient amount of evidence in support of the defendant's guilty plea during the main hearing.

By definition, the prosecutor must discover sufficient evidence which initially should persuade himself/herself, and after that the court, that the suspect or the defendant has committed the crime and that the defendant is guilty for the committed crime. This means that in any case the prosecutor must have sufficient amount of evidence that can persuade the court beyond reasonable doubt that the defendant is guilty for the charged crime. ${ }^{38}$

Additionally, the suspect's guilty plea or statement should not serve as a fact-finding instrument or the suspect's statement cannot be the sole and only evidence upon which the verdict is based. ${ }^{39}$ This means that during the investigate phase the prosecutor should accept the suspect's initiative for sentence bargaining only in cases when the prosecutor, upon the available facts, is persuaded on the level higher than preponderance of evidence and closer to beyond reasonable doubt of the suspects' guilt. ${ }^{40}$

However, in Macedonian scenario it was noted that in some cases the abovementioned principles were not observed or were poorly observed. In practice we have seen that the guilty plea can serve as a fact-finding instrument, while the courts have developed the practice of rare examination of additional evidence besides the defendant's guilty plea and prior convictions. ${ }^{41}$

The statistical data, coupled with data from focus groups with judges point to the conclusion that in most of the cases when the defendant has pleaded guilty or when the court receives the draft-settlement during the pretrial procedure, the judge usually examines only the legality of the guilty plea. This means that in

38 See: Hall, D. E., 'Criminal Law and Procedure', 5thEdition, Delmar Cengage Learning, 2009, pp. 394; Tapper, C., 'Cross and Tapper on Evidence', 12th Edition, Oxford University Press, 2010

39 See more at: Damaška, M., 'Okrivljenikov iskaz kako dokaz u suvremenom krivičnom procesu', Narodne Novine, Zagreb, 1962, pp. 65 ff.

40 See: Viano, E., 'Plea Bargaining in the United States: a Perversion of Justice', Revue Internationale De Droit Penal, vol. 83, no. 1-2, 2012, available at: [https://www.cairn.info/revue-internationale-de-droitpenal-2012-1-page-109.htm\#], accessed 20. June 2020

${ }_{41}$ As is usually performed in the US Federal courts, when judge examines the guilty plea 
such cases, judges are only evaluating whether the guilty plea was voluntary and whether this plea was intelligent. In rare cases judges request additional evidence for support of this guilty plea. Furthermore, in the focus groups it was noted that when defendant has pleaded guilty the judge's position is only formal. They stated that when the judge is faced with a guilty plea they treat it as a confession, unfortunately connecting this guilty plea with the establishment of the long abandoned principle of formal truth. ${ }^{42}$

Hence more, we have not been able to witness situation in court when the judge evaluates the defendant's guilty plea in such manner where the judge would ask the suspect or the defendant to provide detailed explanation how was the crime committed. This is important as necessity to connect this statement or explanation with the submitted list of evidence as integral part of the indictment. ${ }^{43}$

This observed judges' position of over estimating the prosecutors' professionalism, and not taking any additional steps to double check the veracity of defendant's statement may be based upon narrow interpretation of the legal provisions of the LCP. From the observed court cases we can conclude that the judges are narrowly interpreting the provisions of the article 381 paragraph 3, of the LCP, where it is regulated that after the defendant's guilty plea and the evaluation whether this plea is intelligent, voluntary and whether the defendant is aware of the consequences of the guilty plea (paragraph 2 of the article 381), the court will examine only the evidence that are relevant for determination of the criminal sanction.

Due to this, in practice when there is guilty plea, the court usually examines only the evidence connected to the defendant's prior conviction. ${ }^{44}$ This situation relates to the fact that in stricto sensu of the law only the prior conviction is the evidence that is important to determine whether the defendant is a recidivist and in such cases to determine more severe sentence. However, it is needless to mention that under our legal doctrine we do not understand any distinction between the evidence, meaning that there is no distinctive division between the evidence related to the determination of guilt and evidence related to the determination of the

42 This was obvious from the discussions over the presentation of the report. 2019

43 See: Israel, J. H.; Kamisar, Y.; LaFave, W. R., 'Criminal Procedure and the Constitution, Leading Supreme Court Cases and Introductory Text', Thomson West, 2003; Ingram, L. J., Criminal Evidence, 12ed. Elsevier, 2015

44 Even more, from the Annual Reports of the Coalition All for Fair Trials we can conclude that evidence of prior conviction is the most common and usually the only evidence in support to the guilty plea. In over $95 \%$ of the analyzed guilty pleas, while only in several cases (only in 5 cases in the period of 3 years) the court evaluates additional evidence such as expert-witness opinions regarding the defendants' mental health or other evidence, such as financial expert-witness testimony. See CAFT Annual Reports for 2017, 2018 and 2019 
criminal sentence. Furthermore, in some cases, the same evidence could be used for proving the guilt of the defendant, but at the same time, it could be used for determination of the sanction. For example, the evidence of defendants' gambling debts could serve as a proof of the defendant's motive for murdering his/hers grandparent in order to inherit theirs asset, which could serve as evidence for determination of both the type of the murder and the length of the prison sentence.

However, taking into consideration the LCP's provisions that regulates the sentence bargaining and guilty plea, we deem that in such cases, judges do not need to be strict. Henceforward, by the virtue of the law, the judges may request examination of any evidence from the list of evidence that is part of the indictment, which judges need as a factual support or for rebuttal of the defendant's guilty plea.

This idea rests upon the provisions of the article 334, line 2, of the paragraph 1 , which states that while examining the guilty plea, given during the phase of evaluation of the indictment, court examines whether there are sufficient evidence in support to this defendants guilty plea. Despite the fact that this type of guilty plea rarely occurs in practice, the above-mentioned court's position should serve as a model for the evaluation of the guilty plea, which by Macedonian experience, occurs in most cases either when there is sentence bargaining during the investigative procedure, or as a guilty plea during the main hearing. In ideal situation, this would mean that during the examination of the defendant's guilty plea, the court should hear the whole testimony from the defendant, based upon the listed evidence into the indictment. Meaning that the defendant's plea should be in structural connection with the listed evidence, in a way of providing a no contradictory story of one life situation supported with the listed facts.

Further support of this possibility for broader interpretation of the LCP are the provisions of the article 483 paragraph 2, which regulates that after the sentence bargaining procedure the public prosecutor within the signed draft-settlement is obliged to provide all evidence, together with the signed defendant's statement regarding the type and the amount of the indemnification. Meaning that while the court examines the draft-settlement, all evidence should be placed in front of him/her.

This interpretation rests upon the fact that the provisions of the LCP are interconnected and cannot be read individually; however, it is only partial solution for improvement of the above-noticed situation.

Hence, we think that in order to improve the courts practice we need to undertake several activities. First, is to provide detailed commentary of the provisions of the 
LCP, which are regulating the sentence bargaining and guilty plea. Possibly, more important is the need for further legislative improvements and amendments of the LCP's provisions. This improvement will clarify these provisions and make them more strict and precise. In this fashion, LCP should have clear provisions that will regulate the sentence bargaining and guilty plea in a way that will allow the judge to examine any evidence from the list of evidence or from the draft-settlement that judges think is necessary to examine as a factual support to the acceptance of the submitted draft-settlement or guilty plea. Such changes may be simple transformation of the provisions of the article 381 of LCP, or with simple deletion of the word: "sentence" in this paragraph, which would mean that the judges should examine the evidence in support to the defendant's guilty plea.

Additional possibility for improvement of the court's position for evaluation of guilty plea is through the model of information of the defendants' rights while explaining the indictment. This means that in cases when there is guilty plea, the court may request from the defendant to provide detailed plea and detailed explanation of the circumstances of the crime, connecting his/hers statement with the facts from the listed evidence, in connection to the opening speeches of the prosecutor and defense. Furthermore, if defendant is expressing readiness for pleading guilty, but states that he/she does not understand the indictment, than the court should explain the indictment to the defendant, but only in a manner which would simplify the legal jargon to defendant and will not tamper defendant's statement how things have happened. Furthermore, if defendant does not understand the charges even after the courts explanation, we deem that the guilty plea should be consider as unacceptable. Such changes to the article 380 of the LCP will provide further clarification of the guilty plea and will support the court's fact-finding position concerning the evaluation of the veracity of the guilty plea.

Further legislative intervention, than might improve the veracity of the court's practice with the implementation of the sentence bargaining and guilty plea is institutionalization of the sentence hearing. ${ }^{45}$ This is another legal transplant from the original US federal criminal procedure, which will improve the factual support of the guilty plea and sentence bargaining while not jeopardizing the efficiency and effectiveness of the court hearings. This means that in such cases when the defendant has pleaded guilty, the judge should move forward with the procedure to the sentence hearing where the judge would have some type of inquisitorial role of deciding upon the amount of the evidence that should be examined as a support to the guilty plea.

45 See: Sprack, op. cit., note 34; Israel; Kamisar; LaFave, op. cit., note 43 
Although, it seems that such scenario shifts the burden of proof from the prosecutor to the court, in fact it only strengthens the judges' position to request the prosecutor to discover evidence in open court upon the courts need. However, before introduction of this possible solution into the amendments to the LCP's provisions, we think that there should be additional research in order to evaluate its impact towards the concept of the criminal procedure.

\section{CONCLUSION}

Guilty plea and sentence bargaining as two powerful instruments, well known from the comparative criminal procedures, for accelerating the criminal procedure at the same time protecting the scarce judicial assets while not jeopardizing the justice, seems that have not passed the test within the Macedonian criminal justice system. Although there are several legislative issues that need to be improved, we deem that there are serious misinterpretations regarding the practical implementation of these instruments.

Due to these legislative and practical partially inconsistent interpretations of the provisions of the LCP the number of these two instruments is in obvious decline. In this occasion, we have tried to identify the real reasons for such decline of the number of cases resolved using sentence bargaining or guilty plea and to try to determine proper answer to these situations.

One of the biggest flaws, by our opinion, is the fact that while using these instruments judges tend to provide greater trust to the prosecution's case while at the same time strictly and narrowly interpreting the legal provisions in regard to the evaluation of the factual support to the draft-settlement and guilty plea. We think that it is necessary for the judges to improve their proceedings in a way of providing additional effort into critical examination of the evidence in particular cases when there is guilty plea in open court. We deem that the courts while examining whether the defendant's guilty plea is intelligent and voluntary, at the same time must be assured beyond preponderance of evidence and closely to beyond reasonable doubt that the plea is true and it is properly factually supported. Only through such court's practice, we could expect increase of the number of these instruments for accelerated justice in practice and only then, we could expect that the general population will accept these instruments and increases the level of trust and confidence into the judiciary. Hence, it is necessary to undertake several amendments to the LCP that would reduce the possibility of free interpretation of the legal provisions in practice and would make legal provisions clearer and easier to interpret. 


\section{REFERENCES}

\section{BOOKS AND ARTICLES}

1. Alschuler, W., 'The Trial Judge's Role in Plea Bargaining, Part I', Columbia Law Review, vol. 76, no. 7, 1976, pp. 1059-1154

2. Boari, N.; Fiorentini, G., An Economic Analysis of Plea Bargaining: the Incentives of the Parties in the Mixed Penal System', International Review of Law and Economics, vol. 21, no. 2, June, 2001, pp. 213-231

3. Buzarovska, G.; Kalajdziev, G., 'Reform of the Criminal Procedure in the Republic of Macedonia', Iustinianus Primus Law Review, vol. 1, no. 1, 2010

4. Buzarovska, G.; Misoski, B., 'Plea Bargaining in the New Law on Criminal Procedure in Republic of Macedonia', Iustinianus Primus Law Review, vol. 1, no. 2, 2010

5. Buzarovska, G.; Misoski, B., 'Plea Bargaining under the CPC of the Republic of Macedonia', in: Jovanovic, I.; Stansavljevic, M., (eds.), Simplified Forms of Procedures in Criminal Matters - Regional Criminal Procedure Legislation and Experiences in Application, OSCE Mission to Serbia, 2013, pp.223-231

6. Damaška, M., 'Okrivljenikov iskaz kako dokaz u suvremenom krivičnom procesu', Narodne Novine, Zagreb, 1962

7. Fisher, G., 'Plea bargaining's triumph: a history of plea bargaining in America', Stanford University Press, 2003

8. Hall, D. E., 'Criminal Law and Procedure', 5thEdition, Delmar Cengage Learning, 2009

9. Herzog, S., 'Public support for Plea Bargaining Practices', Crime and Delinquency, vol. 50, no. 4, 2004, pp. 590-614

10. Ingram, L. J., Criminal Evidence, 12-ed. Elsevier, 2015

11. Israel, J. H.; Kamisar, Y.; LaFave, W. R., 'Criminal Procedure and the Constitution, Leading Supreme Court Cases and Introductory Text', Thomson West, 2003

12. Jovanovic, I.; Stanisavljevic, M. (eds.), 'Simplified Forms of Procedures in Criminal Matters - Regional Criminal Procedure Legislation and Experiences in Application', OSCE Mission to Serbia, 2013

13. Kalajdziev, G., et al., 'Rearrangement of the Main Hearing in Republic of Macedonia', МРКПК, бp. 2-3, 2008, pp. 213-234

14. Matovski, N.; Kalajdziev, G., 'Efficiency of Prosecutorial Investigation in Contrast to Efficiency of the Defense in Reformed Criminal Procedure (with a particular view of the new Macedonian $C P C$ )', in: Jovanović, I.; Petrović-Jovanović, A., (eds.), Prosecutorial investigation regional criminal procedure legislation and experiences in application, OSCE Mission to Serbia, 2014, pp. 259-270

15. McConville, M., 'Plea Bargaining: Ethics and Politics', Journal of Law and Society, vol. 25, no. 41998 , pp. 562-587

16. Misoski, B.; Avramovski, D., Petrovska, N., 'Anlysis of the Data Collected from the Court Proceeding Monitored in 2017', Coalition All for Fair Trials, Skopje, OSCE, 2018

17. Misoski, B.; Avramovski, D., Petrovska, N., Anlysis of the Data Collected from the Court Proceeding Monitored in 2018', Coalition All for Fair Trials, Skopje, OSCE, 2019 
18. Misoski, B.; Avramovski, D., Petrovska, N., Anlysis of the Data Collected from the Court Proceeding Monitored in 2017', Coalition All for Fair Trials, Skopje, OSCE, 2020

19. Misoski, B.; Ilikj Dimoski, D., 'Judges' Role in the Evaluation of the Defendant's Plea within the Sentence Bargaining Procedure', Journal of the Faculty of Security, University St. Klement of Ohrid, Bitola, 2016.

20. Sprack, J., 'A Practical Approach to Criminal Procedure', Oxford University Press, 10-th Edition 2005

21. Tapper, C., 'Cross and Tapper on Evidence', 12th Edition, Oxford University Press, 2010

22. Yue, M., 'Prosecutorial Discretion and Plea Bargaining in the USA, Germany, France and Italy: A Comparative Perspective', International Criminal Justice Review, vol. 12, 2001, pp.22-52

23. Калајџиев, Г., 'Замки и заблуди на ребормата на истрагата' іп Зборник на трудови на Правните факултети во Скопје и Загреб, ПФ Скопје/PF Zagreb 2009

\section{EU LAW}

1. CoE's Recommendation No. (87) 18, of the Committee of Ministers to Member States Concerning the Simplification of the Criminal Justice

\section{LIST OF NATIONAL REGULATIONS, ACTS AND COURT DECISIONS}

1. Law on Criminal Procedure, Official Gazette, No, 150/2010

2. Official Gazette of the Republic of Macedonia, no 150/2010

\section{WEBSITE REFERENCES}

1. Misoski, B., "Delayed Justice - Macedonian Experience with Guilty Plea and Sentence Bargaining”, SEEU Review, vol. 11, issue 1, 2016, available online: [https://content.sciendo.com/ view/journals/seeur/11/1/article-p99.xml], accessed 20. June 2020

2. Petrovska, N.; Amet, S.; Hadzizafirov, Z., 'Efficient Criminal Justice: Analysis of the SPO Cases, FIOOM, 2020, (in Macedonian), available at: [https://all4fairtrials.org.mk/wp-content/ uploads/2020/04/BP-TA2020-FK-MKD.pdf], accessed 20. June 2020

3. Viano, E., 'Plea Bargaining in the United States: a Perversion of Justice', Revue Internationale De Droit Penal vol. 83, no. 1-2, 2012, available at: [https://www.cairn.info/revue-internationale-de-droit-penal-2012-1-page-109.htm\#], accessed 20. June 2020

4. Бужаровска, Г., 'Невоедначената казнена политика и нејзиното влијание врз спогодуването за кривична санкиија според Законот за кривичната постапка', МРКПК, год. 21, бр. 1, 2014, available at: [http://maclc.mk/Upload/Documents/03.pdf], accessed 20. June 2020

5. Груевска Дракулевски, А.; Мисоски, Б., 'Компаративна анализа на механизмите на упатства за одмеруване казна: Упатството за одмеруване казни во САД', МРКПК, год. 21, бр. 1, 2014, available at: [http://maclc.mk/Upload/Documents/06.pdf], accessed 20. June 2020

6. Каневчев, М., За некои (контроверзни) решенија од Законот за определуване на видот и одмеруване на висината на казната, МРКПК, год. 24, бр. 1, 2017, available 
at: [http://maclc.mk/Upload/Documents/Metodija\%20Kanevchev\%202.pdf], accessed 20. June 2020

7. Тупанчески, Н.; Деаноска Трендафилова, А., Една година од примената на Законот за одредуване на видот и одмеруване на висината на казната - проблеми и предизвици, МРКПК, год. 24, бр. 1, 2017, available at: [http://maclc.mk/Upload/Documents/Tupanceski,\%20Deanoska.pdf], accessed 20. June 2020 